\title{
ENVIRONMENTAL FACTORS INFLUENCING THE SLAUGHTER VALUE AND FLESH QUALITY OF THE COMMON CARP IN FOUR TYPICAL FISH FARMS IN HUNGARY
}

\author{
D. Varga*, Cs. Hancz, P. Horn, T.G. Molnár and A. Szabó \\ Faculty of Animal Science, Kaposvár University, H-7400 Kaposvár, Guba S. u. 40. Hungary
}

(Received: 9 August 2011; accepted: 15 August 2012)

\begin{abstract}
Four important Hungarian common carp (Cyprinus carpio L.) breeds (Attala mirror, Attala scaled, Hortobágy scaled and Szeged mirror) harvested from different fish farms were analysed in this study. Main body indices, slaughter characteristics, fillet fat content, and conventional fish flesh quality characteristics were measured and compared. The slaughter value of the mirror strains tended to exceed that of the scaled type carps. For the calculated body indices (profile, cross-sectional, head and tail index) the influence of strain was statistically proven. Fillet fat content was significantly $(\mathrm{P}<0.01)$ affected by strains/ponds. The $\mathrm{pH}$ value of the fillet was significantly influenced by the strain as a fixed factor. Large, strain dependent variability was proven in fat content besides identical fillet dry matter contents. It was assumed that culture conditions and strain largely influence and lead to a marked variability of the body composition and flesh quality of the most important Hungarian fish species.
\end{abstract}

Keywords: common carp, slaughter value, meat quality

In the freshwater aquaculture common carp (Cyprinus carpio L.) and other cyprinids are the most largely cultivated species throughout the world (Kestemont, 1995). Production and consumption of carp dominate in South-Eastern Asia, Middle and Eastern Europe, and in developed countries of Europe and North America is minimal or nil. Carp production, while Europe shows decreasing tendencies, in India and Indonesia increased significantly the last years. This increase in fish production has corresponded with an increase in the consumption of fish meat as an alternative or substitute for red meat. Besides, carp culture has a great potential for waste utilization and thus for pollution abatement (SumANTADINATA, 1995; Seghal \& Seghal, 2002).

Carp production systems are significantly different around the world. In Europe carp rearing is related to fish farms with semi-intensive polyculture. In Asia the extensive monoculture, the integrated monoculture, and irrigation pond culture also exist (KESTEMONT, 1995). Intensive rearing of carp is not typical anywhere in the world because of the lower value of carp meat (e.g. as compared to the salmonids).

Common carp (Cyprinus carpio) is the dominant species in Hungary's fish production, too, with its share over $75 \%$. This is largely mirrored in the national fish consumption habits as well, since carp is the most consumed fish of Hungary. In parallel with the alterations of the national consumption, the proportion of processed products is increasing, giving a more expressed basis for the research concerning slaughter value and flesh quality.

Common carp is the only domesticated species of the Hungarian fish fauna. The beginning of the domestication is related to the Romans, the main purpose to achieve a higher

\footnotetext{
* To whom correspondence should be addressed. Phone: +36-82-505-800; e-mail: varga.daniel@ke.hu
} 
slaughter value (BALON, 1995). Thus, different common carp strains were developed in Central Europe. The body indices (profile index, tail index, etc.) are used to describe a carp variety or strain (e.g. mirror, lean), and the extent of domestication. Generally mirror variants have a rounder form than scaled carp, and it appears also in the smaller profile and head index.

The most significant comparative quality investigations were done by the National Institute for Agricultural Quality Control (OMMI) in the Carp Performance Tests (CPT). (The last CPT was carried out in 2005.) In the CPT in a two years long period the survival rate, weight gain, growth rate, and feeding conversion were measured of the Hungarian carp varieties. Also, in the second year body shape, slaughter value, and meat quality (fat content and proximate composition of the fillet) were determined.

Besides, HANCZ and co-workers (1995) analysed the alterations of carp body composition after natural and fodder based feeding regimes under laboratory conditions. Moreover, OBERLE and co-workers (1997) investigated the effects of divergent feeding protocols on the fillet composition, but fillet flesh quality was not involved. In the studies of LENGYEL and coworkers (2001); KÖRMENDI and co-workers (2002); ROMVÁRI and co-workers (2002); TRENOvSzKI and co-workers (2008, 2011), and BAUER and SchlotT (2009) mostly the body fat content, the fatty acid profile, and the total body composition was determined. Body shape, slaughter value, and meat quality of carp strains reared under different natural conditions has not yet been compared in the Hungarian carp stocks. The aim of the present study was to compare the above-mentioned properties (such as body shape, slaughter value, and conventional meat quality) of four Hungarian carp breeds.

\section{Materials and methods}

\subsection{Farms}

The farms involved in the study represent the main pond types occurring in Hungary. Three of the farms (TG1, TG2, TG3) are located in South-Transdanubia, the traditional fish farming region of Hungary. The fourth (TG4) lies on the Great Plain (Fig. 1). The main differences between farms are related to their geographical characteristics. The first and second fish farms (TG1, TG2) are in hills, built on clayey soil, behind dams. The third and fourth (TG3, TG4) farms are in plains, built around dikes. TG3 is on peaty soil, there is a large reedy marsh around the ponds; TG4 is on salty, alkaline soil. TG1 and TG2 are filled by streams, TG3 is filled with groundwater and TG4 is filled from the river Tisza and by groundwater.

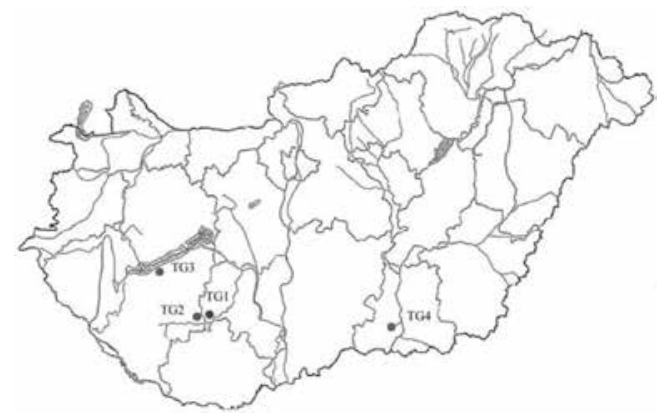

Fig. 1. Location of the four fish farms in Hungary 
Semi-intensive fish production in polyculture is performed at the farms, where the main product is common carp. Table 1 shows the proximate stocking and feeding data of the fish farms. The accurate data of the caught species and the fed fish feed are not available because the farms administer these as trade secret.

Table 1. Proximate basic data of the fish farms

\begin{tabular}{lcccc}
\hline Fish farms & TG1 & TG2 & TG3 & TG4 \\
\hline Size of pond (ha) & 18 & 23 & 15 & 241 \\
Fish nutrition: & & & & \\
Maize (\%) & 80 & 80 & 80 & 80 \\
Wheat (\%) & 5 & 5 & 15 & 20 \\
Triticale (\%) & 15 & 15 & 5 & 0 \\
Rearing regime: & Polyculture & Polyculture & Polyculture & Polyculture \\
Stocked fish species (\%): & & & & \\
Common carp (Cyprinus carpio) & 90 & 80 & 85 & 90 \\
Grass carp (Ctenopharingodon idella) & 5 & 5 & 5 & 2.5 \\
Silver carp (Hypothalmichthys molitrix) & 5 & 12 & 5 & 4.5 \\
Pikeperch (Sander lucioperca) & 0 & 0 & 5 & 0 \\
Catfish (Silurus glanis) & 0 & 3 & 0 & 5.5 \\
\hline
\end{tabular}

Table 2. Slaughtering value, fillet fat content and body shape indexes of the three acknowledged carp strains measured by the Carp performance test (OMMI, 1999, 2000, and 2002)

\begin{tabular}{lccc}
\hline & Attala mirror & Szeged mirror & Hortobágy scaled \\
\cline { 2 - 4 } & $1998-1999$ & $2000-2001$ & $1997-1998$ \\
\hline Slaughtering value (\%) & 62.08 & 65 & 60.5 \\
Profile index & 2.3 & 2.2 & 2.5 \\
Cross-sectional index & 2 & 2.2 & 1.9 \\
Head index & 3.3 & 3.1 & 3.3 \\
Tail index & 2.5 & 2.7 & 2.4 \\
Fat content (\% of wet weight) & $16.61 \pm 1.54$ & $9.38 \pm 1.93$ & $16.07 \pm 1.03$ \\
\hline
\end{tabular}

\subsection{Description of the analysed carp strains}

Altogether 80 market-size common carps (Cyprinus carpio) were taken from the four fish farms. The carps were collected at the harvesting time (November-December, 2010). Different carp strains were reared at farms: TG1: Attala mirror, TG2: Attala scaled, TG3: Hortobágy lean (scaled), TG4: Szeged mirror (Table 2). Every strain was bred as a local type 
of common carp, which adapts well to the regional environment. Three of the strains (Attala mirror, Szeged mirror and Hortobágy scaled) are qualified by OMMI, and acknowledged as a Hungarian carp strain (OMMI, 1999, 2000, 2002).

\subsection{Slaughtering, slaughter value}

Carps were processed after percussive stunning in accordance with the rules of the Carp Performance Testing Codex (OMMI, 2001). Before the conventional processing, the following biometric traits were registered: body length, standard length, head length, tail length, body height, and body width. The following indices were calculated: profile index (body length/body height), cross-section index (body height/body width), head index (body length/head length), and tail index (body width/tail length) (Fig. 2).

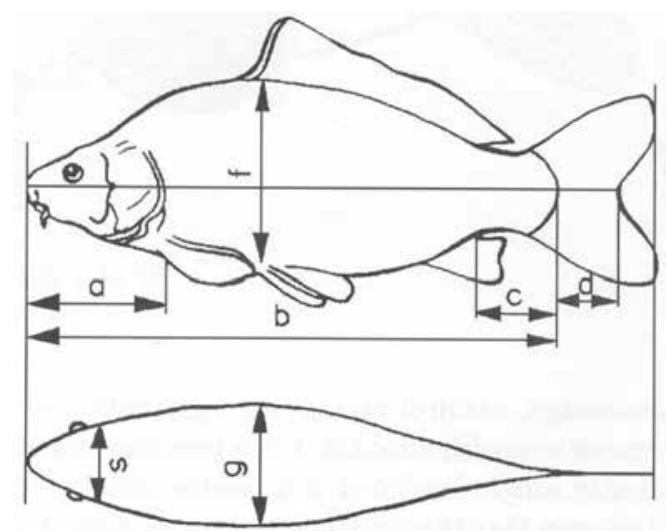

Fig. 2. Calculation of the body-description indices (JÁszFALusı, 1954) (a: head length, b: body length, c: tail length, f: body height, and g: body width)

After the processing the separated parts of the body were measured, and the slaughtering value and fillet yield were calculated. The sex of each individual was determined.

\subsection{Fillet flesh quality investigation}

Fillet $\mathrm{pH}$ was measured at $45 \mathrm{~min}$ and $24 \mathrm{~h}$ post mortem by a Testo 205 precision $\mathrm{pH}$ meter (Testo AG, Lenzkirch, Germany). The colour (CIE Lab, L - lightness, a* - redness, b* yellowness) of the fresh fillet was determined by a Minolta ChromaMeter 300 apparatus (Minolta, Osaka, Japan). Dripping loss was determined by the method of HoNIKEL (1998). To determine the cooking loss, fillet samples $(100 \mathrm{~g})$ were closed into sealed bags and were cooked at $75^{\circ} \mathrm{C}$ for $20 \mathrm{~min}$. The exudate weight, as expressed in the percentage of the initial sample weight, was referred to as cooking loss. The thawing loss was determined by the same manner, i.e. samples $(25 \mathrm{~g})$ were frozen $\left(-20{ }^{\circ} \mathrm{C}\right)$ and thawed to room temperature after 2 days. Moreover, fillet dry matter content was determined by drying to constant weight at $103{ }^{\circ} \mathrm{C}$. Fillet fat content was determined from raw samples by extraction with petroleumether and drying the extract at $103{ }^{\circ} \mathrm{C}$ to a constant weight according to ISO (1985). 


\subsection{Statistical evaluation}

SPSS 10 for Windows (1999) was used for the statistical analysis. The first step was to discard the individual data falling outside the double range of standard deviation. ANOVA (GLM, Univariate) with Tukey's "post-hoc" test $(\mathrm{P}<0.05)$ was used to compare the body shape, slaughtering and flesh quality parameters and to ascertain the between-group differences. Fixed factors were sex and strain. As the four strains represented two varieties (mirror and scaled), differences according to variety were evaluated with t-test. Relation among traits was described by linear regression and correlation.

\section{Results and discussion}

\subsection{Slaughter characteristics}

Data of Table 3 indicate that the slaughter value of the mirror varieties tended to exceed that of the scaled type carps, the Attala mirror strain providing significantly the highest slaughter value. This assumption was underscored by the ANOVA, since strain significantly influenced the slaughter value $(\mathrm{P}<0.001)$. Albeit the sex of fish was expected to influence the investigated traits, its effect was scarcely proven to be significant (Table 3). For the other calculated indices (profile, cross-sectional, head and tail index) the influence of strain was statistically significant. The profile and the head index of the scaled genotypes were higher, as compared to the mirror strains, while the cross-sectional index was identical in all four strains in this study. The above differences were more pronounced when only the two varieties (i.e. scaled vs. mirror) were compared with t-test $(\mathrm{P}<0.001-0.02)$.

Hungarian carp breeders earlier hypothesized that the body shape of the common carp refers to the extent of the domestication (HANCZ, personal communication). Accordingly, rounder form represents a higher level of domestication and besides the better growing performance more favourable dressing percentage and fillet yield were also logically expected. Although all carp strains have typical body shape description indices, their common contribution to slaughter value can be described only by a $R^{2}=0.15$ value $(P<0.05)$. Fillet yield seems to be less related to these indices $(\mathrm{P}>0.05)$. These results are in accordance with the previous findings of HANCZ and co-workers (2002).

Our described data compared to the received data of the CPTs shows large differences (Statistical comparison is not available). Every carp strain reached a higher slaughter value in CPTs (as compared to the fish farm keeping conditions) and unimportant differences were found between the farmed (Table 3) and CPT groups (Table 2) in the body shape indices. It can be explained that the carps tested in CPT formed a more homogeneous cohort, as compared to the farmed carps.

\subsection{Fat content}

The characterisation of the common carp fillet has not yet been tested with conventional meat quality analysis in Hungary. Generally, the main purpose of the national carp quality investigations is to measure the slaughtering yield and fillet fat content. The strongest influence on the fat content is of the feeding regime. Grain-fed carps provide higher body fat contents, as compared to the mostly natural food consumer counterparts (LENGYEL et al., 2001; TRENOVSZKI et al., 2008). The crude fat content of carps caught in natural waters is $3.1 \pm 3.4 \%$, while farmed carp shows values around $10.0 \pm 4.5 \%$ (CSENGERI et al., 1999). In our 


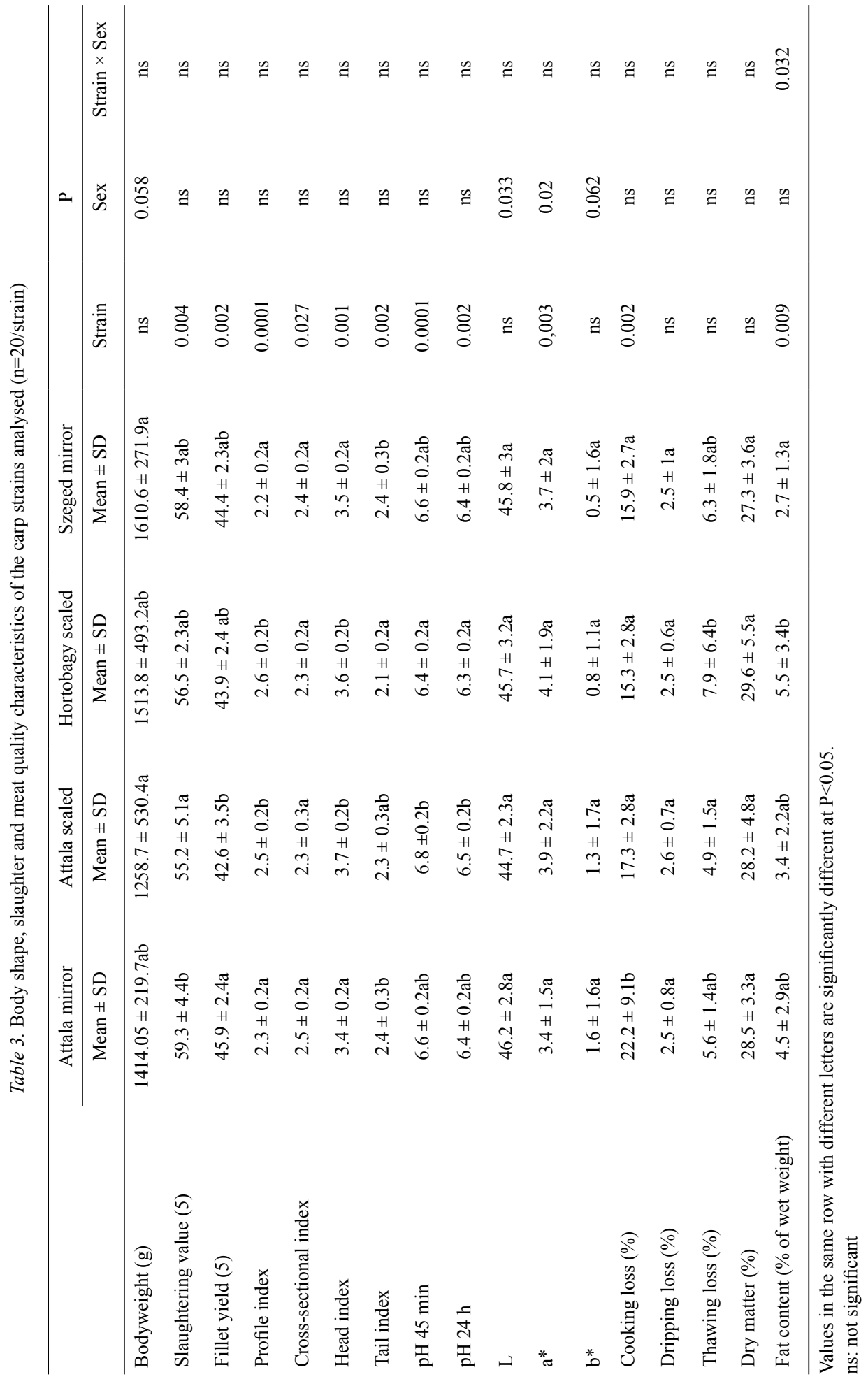


case, the fish feeding regime at the farms was highly similar, but the fat content values falling below the literature data on farmed carps suggest that the natural feed components play important role in the composition of carp diet. BAUER and SCHLOTT (2009) analysed the fat content of carps from three Austrian fish farms with similar rearing conditions as in our study. They published broadly similar fat contents, ranging from 2.7 to $6.9 \%$. According to FAUCONNEAU and co-workers (1995), the body fat content and the body size increase parallel in carp. This was, however, not proven in our study, neither on the total dataset, nor on the datasets sub-ordered according to different strains/ponds. Fillet fat content was significantly $(\mathrm{P}<0.01)$ affected by the strain (Table 3$)$. When analysed by t-test, the difference between mirror (3.62 \pm 2.4$)$ and scaled types $(4.47 \pm 3.0)$ was not significant. This refers to the condition that behind the strains/ponds effect the latter, namely the differing feeding, can be hypothesized. It is worth to mention that Hungarian common carp shows extremely high variance of fillet fat $(\mathrm{CV}=66-67 \%$ for mirror and scaled type, respectively). This value was found earlier to be $21.5 \%$ by HANCZ and co-workers (2002) analysing data of a larger sample of 20 strains studied between 1996 and 2001, where fillet fat content varied around 16\%.

Comparing our data to the CPT dataset revealed also large differences in fat content (Tables 2 and 3). Fillet fat content in the CPT groups were higher (9.36-16.61\%) than the described values $(2.7-5.5 \%)$, most probably due to the more variable feeding at the farms and the different stocking density.

\subsection{Flesh $\mathrm{pH}$ values}

The $\mathrm{pH}$ value 45 min post mortem was always higher than $24 \mathrm{~h}$ post mortem. The betweengroup differences by both $\mathrm{pH}$ values were identical, i.e. the Attala scaled provided the highest values, significantly exceeding the Hortobágy scaled genotype. The $\mathrm{pH}$ value of the fillet was significantly influenced by the strain as a fixed factor.

After the death of fish all biological structures building the tissues will be subject to physical and chemical degradation and decomposition processes. Since blood circulation is cessated, anaerobic metabolism of the muscles is augmented temporarily, and lactate, the end-product, accumulates in the muscles, lowering the $\mathrm{pH}$ slowly in the post mortem phase. Considering the $\mathrm{pH}$ values two important assumptions can be made. At first, the $\mathrm{pH}$ fall in the first $23 \mathrm{~h}$ is very slight, compared to homeotherm vertebrate species. This indicates low glycogen stores in the carp muscles, and this shows general agreement with the results of FAUCONNEAU and co-workers (1995), describing ultimate fillet $\mathrm{pH}$ values over 6 in carps.

\subsection{Water holding capacity}

The induced water holding capacity, as assessed by the cooking loss, was the highest in the Attala mirror strain, with significant strain effects, while the further genotypes provided similar values. The spontaneous moisture loss (dripping loss) did not differ among strains, while the induced moisture loss (thawing loss) was higher in the Hortobágy scaled genotype.

The loss of originally intracellular water (i.e. cytoplasm) off the muscle cells is introduced by tetanic contraction of the muscle fibres, developing the rigor mortis. In this process the protein components of the third filament are degraded, but the disruption of the sarcolemma and that of the sarcoplasmic reticulum also occurs. According to FAUCONNEAU and co-workers (1995) these events take place within a few hours after the development of the rigor and the cessation of the rigor is only achieved when all energy stored are replenished. The extent of this originally natural process is measured by the spontaneous dripping loss of 
the flesh (Honikel, 1998). We obtained ca $2.5 \%$ loss this way, in a strain dependent manner. The explanation of the significant effect is not clear, as there was no detected difference among the strains.

The loss of intracellular fluid can be provoked by different effects, such as freezing and subsequent thawing. Freezing disrupts cellular membranes, the Z-line, and the filamentous structure as well (TAKAHASHI et al., 1993). The degradation process revealed after the thawing is associated with the increase of the $\mathrm{Ca}^{2+}$ concentration around the myofibrils, thus enabling further contraction and fluid loss through the damaged membrane structure. Our study revealed significantly higher thawing loss in the Hortobágy scaled genotype. Albeit the extent of thawing loss is primarily bound to the proteins, interestingly, this analysed carp population had also the highest fillet fat content. These results are in accordance with our former experience (VARGA et al., 2011) that this strain provides significantly higher red muscle contents within the fillet. The extent of the other induced moisture loss, the cooking loss, was, however, rather similar with the only positive exception of the Attala mirror genotype.

\subsection{Flesh colour}

Considering flesh colour $\left(\mathrm{L}, \mathrm{a}^{*}, \mathrm{~b}^{*}\right)$ all fillet samples were identical. The colour characteristics of carp indicate a rather homogeneous population, albeit the strain and even sex exerted a statistically significant effect on all colour measures. Albeit the colour forming organic compounds were not analysed and their cumulative effects were also largely similar (i.e. no colour differences among groups), the effect of fish pond/strain indicates that the benthos and alga composition of the different ponds may affect flash appearance.

\section{Conclusion}

In summary, four important Hungarian carp strains were compared based on their slaughter characteristics and fillet flesh quality parameters. Despite large differences in the body shape and slaughter weight, the $\mathrm{pH}$ and the water holding capacity of the divergent strains were highly similar in the fillet. In contrast, the fillet fat content differed considerably, most probably as a result of the altering additional feeding and natural feed uptake at the different ponds. Our results underscore the practical experience that Hungarian carp population provides large variance (and also as compared to the performance test results) in body composition and slaughter characteristics.

The study was supported by the Hungarian Scientific Research Fund (OTKA), project id. 83150 and by the Bolyai János research grant by the Hungarian Academy of Sciences (BO 26/11/4).

\section{References}

BALON, E.K. (1995): Origin and domestication of the wild carp, Cyprinus carpio: From Roman gourmets to the swimming flowers. Aquaculture, 129, 3-48.

Bauer, C. \& Schlott, G. (2009): Fillet yield and fat content in common carp (Cyprinus carpio) produced in three Austrian carp farms with different culture methodologies. J. Appl. Ichthyol., 25, 591-594. 
Csengeri, I., SÁndor, Zs., Lengyel, P., Györe, K. \& PekÁr, F. (1999): Tógazdasági és természetesvízi ponty (Cyprinus carpio) húsminőségének vizsgálata környezeti, technológiai tényezőkkel összefüggésben. (Meat quality investigation of farmed and natural caught common carp in context the environment and rearing technologies.) Hungalimentaria, Budapest, 1.

Fauconneau, B., Alami-Durante, H., Larochec, M., Marcel, M. \& Vallot, D. (1995): Growth and meat quality relations in carp. Aquaculture, 129, 265-297.

Hancz, Cs., Körmendi, S. \& BÁnhegyi, P. (1995): Egynyaras ponty nevelése természetes táplálékon és abraktakarmányon. (One-year old carps feeding natural food and grains.) Halászatfejlesztés, 18, 172-175.

Hancz, Cs., Stettner, G. \& Demeterné, P.T. (2002): A magyar pontyfajták növekedésének, takarmányértékesítésének, testalakulásának és zsírtartalmának összefüggései. (Growth rate, feed conversion, body shape, and fillet fat content in Hungarian carp breeds.) Halászatfejlesztés, 26, 96-98.

Honikel, K.O. (1998): Reference methods for the assessment of physical characteristics of meat. Meat Sci., 49, $447-457$.

ISO (1985): Animal feeding stuffs - Determination of fat content. International Organization for Standardization. No. ISO 6492

Jászfalusi, L. (1954): Pontynemesítés (Carp breeding). -in: Maucha, R., Erös, P., DonÁszy, E. (Eds.) Tógazdasági haltenyésztés a gyakorlatban. (Fish pond based fish rearing in the practice.) Mezőgazdasági Kiadó, Budapest, Hungary. pp. 172-195.

Körmendi, S., Varga, L., Balogh, I., Hideg, B. \& Széli, Zs., (2002): Ponty testanyag-összetételének szezonális változása tógazdaságokban. (Seasonal change of the body composition in farmed carp.) XXVI. Halászati Tudományos Tanácskozás, Szarvas, p. 35.

Kestemont, P. (1995): Different systems of carp production and their impacts on the environment. Aquaculture, 129, 347-372.

Lengyel, P., Sándor, Zs., Györe, K., Szabó, P., Pekár, F., Zubkova, E., Alexis, M. \& Csengeri, I. (2001): A ponty és néhány más hazai pontyféle testösszetételének alakulása a takarmányozással összefüggésben (Body composition changes in carp and other cyprinids in context of the feeding.) Halászatfejlesztés, 26, 153-162.

Oberle, M., Schwarz, F.J. \& Kirchgessner, M. (1997): Growth and carcass quality of carp (Cyprinus carpio L.) fed different cereals, lupine seed or zooplankton. Arch. Anim. Nutr., 50, 75-86.

OMMI (1999): Ponty teljesitményvizsgálat eredményei 1997-1998. (Results of carp performance testing 19971998) OMMI, Budapest, 51 pages

OMMI (2000): Ponty teljesitményvizsgálat eredményei 1998-1999. (Results of carp performance testing 19981999) OMMI, Budapest, 46 pages

OMMI (2001): Ponty teljesitményvizsgálati kódex 3. (Carp Performance Testing Codex 3.) OMMI, Budapest, 35 pages

OMMI (2002): Ponty teljesitményvizsgálat eredményei 2000-2001. (Results of carp performance testing 20002001.) OMMI, Budapest, 45 pages

Romvári, R., Hancz, Cs., Petrási, Zs., Molnár, T. \& Horn, P. (2002): Non-invasive measurement of fillet composition of four freshwater fish species by computer tomography. Aquacult Int., 10, 231-240.

Seghal, H.S. \& Seghal, G.K. (2002): Aquacultural and socio-economic aspects of processing carp into some valueadded products. Bioresour. Technol., 82, 291-293.

SPSS FOR WINDOWS 10 (1999): Copyright SPSS Inc., 1989-1999

Sumantadinata, K. (1995): Present state of common carp (Cyprinus carpio L.) stocks in Indonesia. Aquaculture, 129, 205-209.

Takahashi, K., Inoue, N. \& Shinano, H. (1993): Effect of storage temperature on freeze denaturation of carp myofibrils with $\mathrm{KCl}$ and $\mathrm{NaCl}$. Nippon Suisan Gakkaishi, 59, 519-527.

Trenovszki, M., Hegyi, Á., Lugasi, A., Kertészné, L.V., Müller, T., Szabó, T., Urbányi, B. \& Horváth, L. (2008): Pontyok takarmányozásának és húsminőségének összehasonlítása különböző tógazdaságokból, illetve egy ketreces kísérletből származó minták analizálásával (Comparative study of the feeding and meat quality of carp from different farms and one-caged experiment.) XXXII. Halászati Tudományos Tanácskozás, Szarvas, p. 36.

Trenovszki, M.M., Lebovics, V.K., Müller, T., Szabó, T., Hegyi, Á., Urbányi, B., Horváth, L. \& Lugasi, A. (2011): Survey of fatty acid profile and lipid peroxidation characteristics in common carp (Cyprinus carpio L.) meat taken from five Hungarian fish farms. Acta Alimentaria, 40, 153-164.

Varga, D., Szabó, A., RomvÁri, R. \& Hancz, Cs. (2011): Elözetes tanulmány vörösizom arány makroszkópos meghatározására és összefüggése a húsminőséggel hazai pontyfajták esetén (Preliminary study of determination the red muscle ratio by a macroscopic method in Hungarian carp breeds, and its relationship to the meat quality.) Acta Agraria Kaposvariensis, 15, 85-90. 